\title{
Library Management in Increasing Reading Interest of Female Santri Dayah of Muslimat Samalanga
}

\author{
Barrulwaliddin $^{1}$, Yusnadi ${ }^{2}$ Ishak $^{3}$, Raudhatul Juniati ${ }^{4}$, Tuhfatul Athal ${ }^{5}$ \\ 1,2,3,4,5 Institut Agama Islam (IAI) Al-Aziziyah Samalanga, Bireuen Aceh, Indonesia \\ Email:walidinmh@gmail.com
}

\begin{abstract}
:
This research is motivated by the management of library management, development of book collections, supporting and inhibiting factors as well as an increase in students' reading interest. This study aims to determine the role of libraries, namely librarian, collection, management management and increase the interest in reading fondness for Dayah Putri Muslimat Samalanga santri, Bireuen Aceh Regency. The purpose of this study was to identify and describe the planning, procurement, use, inventory, deletion, inhibiting and supporting factors of libraries in Dayah Putri Muslimat Samalanga. This research is a qualitative research using descriptive method. Data collection was carried out by interview, observation, and documentation study. The data analysis technique was carried out through descriptive interpretation, data validity testing, participation extension, and auditing. Library planning is carried out by musyarawah, organizing is carried out by selecting and mutually agreed upon, implementation is carried out in accordance with the plan and according to their respective duties and supervision is carried out every day such as supervision of circulation and cleaning services, tidiness and discipline. Collection development is carried out by deliberation and submissions from visitors, the supporting factor is the routine allocation of funds from the dayah for the development of the Dayah Putri Muslimat library and librarians who equate it, the inhibiting factor is that the available librarians are not graduates from their fields.
\end{abstract}

Keywords: management; library; reading interest

\section{Introduction}

The dayah library is a place to add reading sources for students apart from those that have been obtained from teachers in the classroom. Apart from students, teachers, students, lecturers and the community desperately need a library that provides literature to support learning materials. The existence of a library as a place to obtain information is considered very urgent to create quality human resources. The school library according to the Indonesian National Standard is a library located in a formal education unit in the primary and secondary education environment which is an integral part of the school activities concerned, and is a learning resource center to support the achievement of the educational goals of the school concerned. (Rusli, 2016)

A good library is a library that is able to meet the needs and desires of the community at school and is provided with good facilities. Because an inadequate library will lead to a lack of visitors in the library. A library with complete facilities will encourage students to love reading. The library is an appropriate recreational facility for students and even in their spare time at school students should be accustomed to reading books in the library. A library that is complete with adequate facilities will certainly make students comfortable in the library and can foster students' interest in reading. (Risma Niswaty, 2020) 
However, in fact, the reading interest of the Indonesian people is still very low. This is in accordance with the results of a survey from UNESCO. UNESCO says that Indonesia is second from the bottom in terms of world literacy, meaning that reading interest is very low. According to UNESCO data, the reading interest of the Indonesian people is very concerning, only $0.001 \%$. This means that out of 1,000 Indonesians, only 1 person is avid reader. (Devega, 2017). One way to overcome the lack of interest in reading is to present a library that has facilities that visitors like. Library facilities are very important because they can facilitate and facilitate the activities of library users. Good facilities such as a complete and varied collection of library books, adequate library furniture and equipment, and a comfortable room away from noise will create a pleasant atmosphere for students and teachers. To obtain an adequate library and in accordance with the National Library Standards, library development is required.

Library development is carried out with the intention that libraries are able to provide sources of information, science, and technology, as well as meet the needs of the school community. According to Sutarno, The guidance that is carried out includes all aspects of the library, namely: "(a) collection of library materials, (b) human resources, (c) buildings and rooms, (d) budgets, (e) facilities and infrastructure, (f) cooperation partners, ( $g$ ) furniture and fittings, (h) library services, (i) public users. (Risma Niswaty, 2020). Dayah Putri Muslimat Samalanga is a dayah that is open to receiving renewal. This can be seen from the implementation of integrated Islamic education, namely through salafiyah dayah education and formal Muslimat private junior and senior high school education. To complement the information literacy needs of the students, the dayah opened a library as a reference service center. However, the reality is that after a long time the dayah library has been operating, visitors still look lonely. Only a few students allocate their time to visit the library.

The dayah's efforts to enrich knowledge have not been welcomed by the majority of students. Based on preliminary observations, the causes of the lack of library visitors are identified by several factors, among others; (a) too busy routines that must be followed by students, (b) there is still very low interest in students to study science comprehensively, (c) the lack of book collections available in the library, (d) library facilities are still very minimal, (e) there are still many books that have not been codified, ( $f$ ) there is no library program to increase the number of visitors and borrowers, (g) lack of human resources owned by library managers. Programs that are considered new in the world of dayah should be welcomed by the students. Dayah who is willing to open up to the times will not produce graduates who are knowledgeable, have broad insight, have a high enthusiasm for learning, and have competitiveness on a regional, national and global scale without fostering interest in learning among students. One way that the dayah might take is to increase the reading interest of the students through good library management.

Good library management can certainly increase the number of visitors and borrowers in the library. Various types of services are available, the existence of quality human resources in managing the library, the availability of adequate facilities and infrastructure, the existence of various collections needed by users, and there is a special allocation of funds for library development, so an increase in library users is a necessity. Based on the explanation above, the writer is interested in conducting research at Dayah Putri Muslimat Samalanga. The problems that will be studied are how library management in increasing the reading interest of Dayah Putri Muslimat Samalanga students, what are the supporting and inhibiting factors in the library management of Dayah Putri Muslimat Samalnga. 
After doing this research, it is hoped that the writer will be able to know the library management of Dayah Putri Muslimat Samalanga. In addition, the authors can also identify supporting and inhibiting factors in the management of the Dayah Putri Muslimat Samalanga library. The results of this study are expected to be used as evaluation material for the library manager of the Dayah Puteri Muslimat Samalanga, besides that, they can also be input and material for consideration for other dayahs in managing the library.

Research on libraries has been carried out by many previous researchers, one of which is research conducted by HM. Mansyur in his journal "School Library Management". The similarity of this research with the research conducted by researchers is to discuss libraries in educational institutions, meaning that library users are only limited to participants or educational actors in certain educational institutions. As for the difference, the research that the researchers conducted was research on library management in increasing reading interest in Dayah Puteri Muslimat Samalanga.

Other research was also conducted by Heris Hermawan, et al in a journal entitled "Library Management in Increasing Students' Reading Interest". This research examines the management of the school library at Madrasah Aliyah Negeri 3 Tasikmalaya. The difference with the research that the researchers did was the different types of collection requirements and time allocations, considering that the research that the researchers conducted was the dayah library.

There are also many books that have been written about library management, including the book by Ibrahim Bafadal "Management of the School Library, and the work of Said Maskur et al" Library Management ". The book writes about ideal libraries and good library management to increase the number of library users. The theory is built based on the results of research in several places over a long period of time, so as to produce a good conclusion in the field of library management. Meanwhile, the research conducted by researchers was limited to the Dayah Putri Muslimat Samalanga library in Bireuen Regency and in a short period of time, namely for only two months. So that the research conclusions that the researchers have done cannot be used as a theoretical standard in library management at large.

\section{Review of Literatures}

\subsection{Library Management}

Management is a management process that utilizes human resources and other resources through planning, organizing, implementing and monitoring to achieve desired goals effectively and efficiently. Library comes from the word library, according to the Big Indonesian Dictionary, meaning book. In English it is known as a library. This term comes from the word librer or libri which means book, from the Latin word the term libraries about books is formed. In Dutch, the library is called binliotheca which also comes from the Greek Biblia which means about books or books (Suwarno, 2010). Management in the library can be explained by organizing, directing, guiding, controlling, influencing staff or librarians so that they can work, work, carry out librarian duties to achieve the goals of the library. From this understanding, management in the library needs to be studied, understood, and realized by library leaders in order to achieve the tasks, functions and goals of the library (Iskandar, 2016).

Management is an activity, its implementation is called managing and the person who does it is called a manager, an individual who becomes a manager, new tasks are entirely management in nature, management includes activities to achieve goals carried out by 
individuals who contribute their best efforts through management actions. predetermined (Mansyur, 2015).

Supyardi argued that a school library is a library organized in schools to support teaching and learning programs at formal education institutions at the school level, both primary and secondary schools, both public and secondary schools. Meanwhile, according to Carter V Good, the library is a collection organized in a room so that it can be used by students and teachers (Bafadal, 2015). According to Law No. 43 of 2007 Article 1 concerning Libraries, it is stated that a library is an institution that manages collections of written works, printed works and recorded works in a professional manner with a standard system to meet the needs of education, research, information preservation and recreation of visitors. Meanwhile, according to Wafford, he explained that the library is a learning resource organization that stores, manages and provides library materials, both books and non-books to certain people and the general public (Rokan, 2017).

The scope of library activities is closely related to the definition of the school library. There are three main library activities, including gathering, managing, and disseminating information. In terms of collection, this task includes activities to find, select, and fill the library with adequate or complete information sources, both in terms of quantity, type, and quality, all of which are adjusted to organizational policies, availability of funds, user desires, and recent developments. Meanwhile, in terms of management, its duties include processing, compiling, storing, and packaging so that it is neatly arranged, easy to search and easily accessible to users, as well as caring for library materials. Processing work includes maintenance and maintenance so that the entire library collection remains in clean condition, whole, and good. Meanwhile, managing activities in the sense of caring are activities carried out in the framework of maintenance and protection in order to maintain historical values and documentation. While the last activity is the dissemination of information, some of the tasks included in this activity are reference and information services, collection loan services, promotional services, guidance services to readers, and so on. Included in this are services to students and teachers in order to find information related to their fields and interests (Prastowo, 2012).

\subsection{Library Management Functions}

Libraries, including school libraries, should carry out management functions as the basis for their management, namely planning, organizing, staffing, directing, and controlling. Furthermore, school library management must be guided by these five aspects, namely as follows:

\section{a. Planning}

Planning is one very important aspect of the school library management process. There are several important things to think about in the planning stage, namely:

1. Determine the purpose of the library

In determining goals, librarians can work with teachers to determine material or materials appropriate to the level of education, to determine the skills needed by students, to assist in the provision of materials in accordance with the subjects being taught.

2. Identify users and their needs

Manage the library to meet the needs of its users. The materials or sources of information in the library need to be arranged as well as possible so that teachers and students who need them can get them quickly, precisely, and accurately. 


\section{b. Organizing}

Organizing is the preparation of organizational structure related to the objectives and in accordance with the resources owned without ignoring the surrounding environment.9 Organizing is done after finishing setting goals and planning carefully, steadily, neatly, carefully, and precisely.10 The organizing process includes activities or efforts in distributing tasks based on expertise by determining what tasks must be done, who should do it, how to do it, how to classify those tasks, who should report to whom, and where the decision should be made. (Irma et al, 2020). Organizing or managing the school library is the responsibility of the school librarian. Organizing is an aspect of management that concerns the preparation of human and material organizations. These activities include:

1. Arrangement of efficient loan services to teaching staff and students;

2. Providing an efficient system regarding ordering services for materials or collections in schools;

3. Provide a flexible system for students, both individually and in groups, as well as teaching staff to use the school library as the purpose of the teaching and learning process;

4. Running a system that allows information sources in the form of hardware;

5. Organize the production of learning resources in the school library (if any) and

6. Supervise and organize work for librarians or other library staff.

\section{c. Staffing}

Staffing is the activity of organizing, monitoring, and coaching staff according to the duties and responsibilities given based on their abilities and skill areas. In this staffing activity, a school librarian must know the techniques and processes required in staff recruitment, staff training, communication with staff, and service to staff.

\section{d. Direction}

In the context of the school library, direction is the responsibility of the library leader. In other words, the role of a leader is really needed in encouraging the staff they lead so that they can work optimally to achieve the desired goals.

\section{e. Controlling}

The school librarian must be aware of the importance of control in an organization, including the library. The things that need to be considered in the aspect of control in the school library include:

1. Always be aware of the goals that are being implemented;

2. Avoiding inefficient activities;

3. Evaluation of services that have been performed.

\subsection{Reading Interest}

Reading interest is a tendency or a high heart's desire to read (Siregar, 2005). Reading interest is a mental tendency that encourages someone to do something about reading. Increasing interest in reading will improve the quality of human resources. Teachers and librarians are the spearheads in increasing people's interest in reading. Libraries are not just for student and student consumption. Therefore, various efforts must be made to increase public interest in reading. Interest has a very big effect on learning, because if the learning material being studied is not in accordance with the student's interest, there is no attraction for him. Lessons that attract students' interest, are easier to learn and easier to store in memory, because interest increases active learning (Sari, 2016). 
There are five stages of reading development, namely reading readiness, pre-reading, speed reading skills, extensive reading and real reading (Triatma, 2016). The use of libraries reveals that there are other ways a person can get information, namely by utilizing electronic media such as TV, radio to smartphones. However, this should not make you forget printed works that provide actual news or information such as articles, newspapers and even books. Furthermore, it is stated in articles 49 to 51 that the point is that the culture of fond of reading can be moved through the use of libraries. However, in reality the use of libraries in Indonesia is relatively low and only $10 \%-20 \%$ of the number of visitors who borrow books (Rivalina, 2007). Increasing interest in reading or reading fondness is one of the roles of the library as a source or provider of information. Thus students are expected to always use the library collection in order to increase reading interest. UU no. 43 of 2007 Chapter XIII regarding the cultivation of a penchant for reading, Article 48 paragraph 3 states that the cultivation of reading fondness in educational units as referred to in paragraph 1 is carried out by developing and utilizing libraries as a learning process.

Randall and Godrich argued that there are four functions of library collections, including: (1) reference function, which means that library collections that have a reference function are library collections that can provide references to various information quickly, precisely and accurately for its users; (2) curricular function, that is, library materials that have a curricular function are collections of materials capable of supporting the curriculum. So the school librarian must be able to meet the needs of visitors by providing a variety of materials and subjects (subjects) taught in the school concerned; (3) general function, that is, the function of library collections which are general in nature related to the preservation of library materials and the results of human culture as a whole; and (4) research function, that is, the existence of a school library collection must be able to provide answers to the curiosity of library users. That way, libraries can be used as a means of providing various information needed by readers or researchers in carrying out their duties (Iskandar, 2016).

\section{Research Methods}

Broadly speaking, the research methodology will explain the stages of the activities carried out, namely: 1) determining the research approach and method, 2) determining the type of data and data sources, 3) data collection techniques, 4) data analysis techniques, 5) determining the place and time of research, and 6) data validity test. The data collection technique is done by interviewing, observing, and studying the documentation. Researchers conducted interviews through question and answer conversations to obtain information from sources. Observations are made through observation either directly or indirectly by using all the senses. Documentation studies are carried out to collect documents and supporting data related to research. The research data analysis technique starts from data analysis before being in the field, data analysis in the field, namely data reduction, data presentation, verification / conclusion, and data analysis while in the field. Meanwhile, the validity of the data consisted of extending observations, increasing persistence, triangulation, negative case analysis, using reference materials and holding memberchecks. The data validity test is carried out to prove that the data received is the actual data found at the research site. 


\section{Results and Discussion}

\subsection{Library Management in Increasing Reading Interest of Dayah Putri Muslimat Samalanga Santri}

Planning for library management procurement at Dayah Putri Muslimat Samalanga begins with planning library facilities and infrastructure, procurement of library materials and planning library work. Meanwhile, the facilities owned by the Dayah Putri Muslimat Samalanga library currently have several inventories, although they are still incomplete. However, with the planning for the provision of new library facilities and infrastructure, this problem can be resolved gradually in order to create a comfortable library for visitors. The Dayah Putri Muslimat Samalanga Library also regularly plans library work programs. Work planning at the Dayah Putri Muslimat Samalanga library includes daily work program planning, weekly, monthly work program planning and annual work program planning that can be formulated in a work program.

In planning the work program, the Dayah Puteri Muslimat Samalanga library always involves all librarian staff, the head of the Dayah Putri Muslimat Samalanga private high school and junior high school, representatives from the Dayah Putri Muslimat education section, the foundation, representatives of homerooms, and representatives of students as facilitators in conveying their opinions regarding procurement of books. With the aim of producing maximum planning. Organizing is a grouping of people according to the activities to be carried out in an organization or commonly referred to as an organizational structure. The organizational structure is one part that shows all its work duties, the relationship between the functions in it, the authorities and responsibilities of each part of the organization's work to achieve the goals that have been planned or determined. Without a library organizational structure, it can be said that it will not run well, because each sector requires its own officers so that there is no imbalance in the implementation of library assignments.

The organizational structure of the Dayah Putri Muslimat library consists of the head of the library, the technical section, the non-technical section, and the service department. Due to limited personnel in management, several parts of the structure are managed by only one person concurrently in more than one position. As in technical and non-technical fields. An effective leadership style states that a good leadership style is a leadership style that can provide work motivation to subordinates. Employees can view their leadership as an effective leader or not, based on the satisfaction they get from the overall work experience. Employee performance will be good if the leader can provide the right motivation and the leader has a leadership style that is acceptable to all employees and supports the creation of a good working atmosphere (Ambarwati, 2015).

The head of the library is in charge of all activities in the library and is in charge of providing direction, guidance and supervision to all library staff. The head of the library is the leader or library manager and is in charge of planning, directing or mobilizing, implementing and supervising activities in the library and the head of the library is responsible to the foundation. The non-technical part of the library is in charge of managing administration or administration and non-technical activities in the library, the non-technical part of the library is responsible to the head of the library. Furthermore, the technical section of the library is in charge of procuring collections, arranging collections, compiling books according to their classification, coding books, and maintaining available collections. The technical department is responsible to the head of the library. The last is the library services section in charge of library services and library promotion. The library service department is responsible to the head of the library. 
Movement (Actuating) can be carried out after planning and organizing, because mobilization is the implementation of the planning and organizing process. The movement in the Dayah Putri Muslimat Samalanga library is service. Services at the Dayah Putri Muslimat Samalanga library means that library staff not only serve borrowing, returning and renewing books, but there are several other services provided, namely circulation services, user guidance services, information literacy services, reference services, information repackaging services and reading and discussion room services. Circulation services are carried out with an open system, in which users can directly select and collect the required library materials themselves. Basically, circulation serves borrowing, returning and extending library materials.

In addition to circulation services, there is also user guidance services, this service is provided to users who need guidance in the use of the library, especially in information retrieval. The third service is information literacy services, this service can be provided to teachers who need collaboration with librarians in the learning process, but users of this service must first contact the librarian. The fourth service is a reference service, this service at the Dayah Putri Muslimat Samalanga library is provided to users who use reference library reference materials that can only be read on the spot and cannot be borrowed to take home, reference collections can be in the form of dictionaries, encyclopedias, geographic sources, guides, bibliographies, student and student papers and guidelines. The fifth service is the information repackaging service. The Dayah Putri Muslimat Samalanga library provides information repackaging services in a simple form, what this service means is the provision of information services starting from selecting various information from various different sources. Registering relevant information, analyzing, synthesizing, and presenting information in accordance with the needs of users. The last service is reading and discussion room services. The services provided by the library and arranged by the librarian are in the form of a place for reading and discussion activities for those who are not interested in borrowing library books to take home. The Dayah Putri Muslimat Samalanga Library provides hours of service, such as from class hours to the end of lessons.

Supervision at the Dayah Putri Muslimat Samalanga library is carried out by the head of the library. Supervision is carried out every working day. The supervision carried out by the head of the library includes supervising the performance of the librarian, supervising the cleanliness of the library, monitoring the neatness and arrangement of the book collection on the shelf in the library, monitoring the circulation (borrowing, returning and extending) the purpose of seeing the number of books borrowed. , books most frequently borrowed and books that have not been returned and supervise existing facilities in the library.

In increasing the reading interest of students, the Dayah Putri Muslimat Samalanga library runs several programs, including renovating the library room, increasing the number of mobilers available, decorating the library room to make it look more attractive, coding books that have not been coded, and adding a number of new book collections. To date, library materials have been procured in the Dayah Putri Muslimat Samalanga library in two ways, namely through purchases and grants. For the method of purchase, books that are held are books and additional books other than those that are required to be owned by all students. The implementation is carried out every year or every curriculum change, because there is a big possibility that a change in curriculum will have an impact on the needs of the library collection. As well as requests from users regarding the library materials needed, however, this is adjusted to the state of the budget. 
Whereas the procurement of book collections by means of grants or prizes is obtained from two sources, namely at the end of each year students and students who will graduate are encouraged to donate books to the library voluntarily (not under duress and it is not determined what books should be donated), both in the form of books. fiction, non-fiction, lessons, religion, or references as long as it does not contain criminalization and SARA and the book must be suitable for use in Dayah Putri Muslimat Samalanga. The next book procurement, namely from the head of the library and the time is not certain, the submission starts from the students to the teacher, is submitted to the librarian and conveyed to the head of the library. Because the requests came from students, most of the requests that were wanted were fiction books.

After several changes, the number of visitors to the library seems to have increased more than before. The number of book borrowers has also increased dramatically. Although the most popular books are fiction story books, such as novels, comics and so on. The head of the library responded positively to the change. He argued "let the students' interest in reading grow first, then we will direct it to select reading materials that can enrich knowledge, especially in the subject areas applicable in the dayah curriculum".

\subsection{Supporting Factors and Barriers to Management of the Dayah Putri Muslimat Samalanga Library}

In the process, management will never be separated from the supporting and inhibiting factors. What is certain is that there must also be library management, supporting factors are anything that can support the implementation process of library management, while the inhibiting factor is anything that can smoothly tackle the implementation of library management. Included in the supporting factors for the management of the Dayah Putri Muslimat Samalanga library are: 1) adequate librarian, namely the head of the library and 2 people who work in the library, 2) members consisting of quite a lot of Dayah Putri Muslimat Samalanga students, so that the library is always visited every day, 3) Most of the available facilities support the service process, for example adequate reading and discussion desks. And there is also a lesehan area for readers who will read, 4) the location of the library is very strategic, the Dayah Putri Muslimat Samalanga library is in the middle of a location far from the noise of the highway and canteen so that it becomes comfortable for visitors to enjoy reading, 5) the Dayah Putri Muslimat environment strongly supports the existence of a library. Because the library is a source for learning that provides various information needed by students and teachers as well as all people in the dayah environment to support the learning process, and 6) The Dayah Putri Muslimat Samalanga library is in the middle of a location far from the noise of the highway and the canteen so that it becomes comfortable for visitors to enjoy reading.

Meanwhile, the inhibiting factors in the library management of Dayah Putri Muslimat Samalanga are: 1) the quality of librarians is not in accordance with their expertise, because the officers are not graduates from the library study program. However, in improving skills in performance in the library always following training and upgrading, 2) there are still many members who are not aware of the importance of the library and visit it to study or read books, 3) teachers still rarely visit the library, teachers should be diligent to visiting the library to add learning materials and at the same time giving examples to the students, 4) there are some books that are still incomplete for teaching materials, this is due to a change in curriculum, 5) some of the facilities are already damaged 


\section{Conclusion}

The Dayah Putri Muslimat Samalanga library service has been categorized as complete as a library in an educational institution. The constraints in library management have also been addressed gradually from year to year. Most of the students' interest in reading is only in fiction books, however, to foster interest in reading first this can still be considered true. The emphasis on compulsory reading only on textbooks will make students lazy to enter the library, which in turn causes lonely visitors to the library.

In carrying out library management, Dayah Putri Muslimat should make a writing competition, such as determining a certain theme about actual legal ploblematics, then giving prizes for the best writing for several winners. Usually, in accordance with human nature, if given motivation, especially in the form of giving a number of prizes, it will spark the interest of the participants to compete with each other to become champions. This kind of program can be a trigger for students to visit the library to find appropriate references and materials to complete their writing.

\section{References}

Abdul, R. (2013). The Influence of Individual Characteristics, Motivation and Work Culture on Employee Performance in the Family Planning Agency and Women's Empowerment in Donggala Regency. E-Journal CATALOGY, 1 (2). http://jurnal.untad.ac.id/jurnal/index.php/Katalogis/article/view/3176

Aini, P. (2012). The Use of Libraries to Increase Students' Reading Interest (Case Study of AnNisaa Pondok Aren Bintaro School) [Thesis, UIN Syarif Hidayatullah Jakarta].http://repository.uinjkt.ac.id/dspace/handle/123456789/5867

Ambarwati, N. (2015). Effective Leadership Style In Efforts To Improve Employee Performance At PT Sumber Mas Indah Plywood. AKUNESA Journal of Accounting, 3 (3), 1-25.

Bafadal, I. (2015). School Library Management. PT Bumi Aksara.

Irma, A. et al. (2020). Communication Management of Islamic Sharia Agency in Applying Women's Islamic Fashion in Banda Aceh. Budapest International Research and Critics Institute-Journal (BIRCI-Journal). P. 576-587.

Iskandar. (2016). Library Culture and Management. PT Refika Aditama.

Kurniawati, RD, \& Prajarto, N. (2015). Role of Libraries in Increasing Public Reading Interest (Survey at Public Library of South Jakarta Municipality). Periodic Library and Information Science, 3 (7). https://doi.org/10.22146/bip.8271

Mansyur, M. (2015). School Library Management. Pustakaloka: Journal of Information and Library Studies, 7 (1). https:// doi.org/10.21154/pustakaloka.v7i1.184

Prastowo, A. (2012). Professional School Library Management. Diva Press.

Rahadian, G., Rohanda, R., \& Anwar, RK (2014). The Role of School Libraries in Improving Reading Culture. Journal of Information and Library Studies, 2 (1), 47. https://doi.org/10.24198/jkip.v2i1.11628

Rahman, TMA (2019). Library Management Based on Automation System. Isema's Journal: Islamic Educational Management, 3 (2), 114-124. https://doi.org/10.15575/isema.v3i2.5015

Rokan, MR (2017). School Library Management. IQRA ': Journal of Libraries and Information, 11 (1), 88. https://doi.org/10.30829/iqra.v11i01.795

Sari, P. (2016). Reading Interests of Class XI Students of SMK Negeri 1 Kebumen Against Popular Novels. Journal of Indonesian Language and Literature Education, 5 (9), 1-9. 
Siahaan, S., \& Rivalina, R. (2007). Strategies to Increase Reading Interest: Making Reading a Daily Habit. TEKNODIC Journal, 11 (2), 168-186.

Siregar, AR (2005). Knowledge Management: The Librarian's Perspective. PUSTAHA: Journal of Library and Information Studies, 1 (1). http://puslit2.petra.ac.id/ejournal/index.php/pus/article/view/17239

Suwarno, W. (2010). Basic Literature Knowledge. Ghalia Indonesia.

Triatma, IN (2016). Reading Interest in Grade VI Students of Delegan 2 State Elementary School, Prambanan Sleman Yogyakarta. E-Journal of Thesis, Educational Technology Study Program, 5 (6), 166-178. 